\title{
Responses of adolescents regarding the indispensable role of the Christian father as mentor within the family: A qualitative study
}

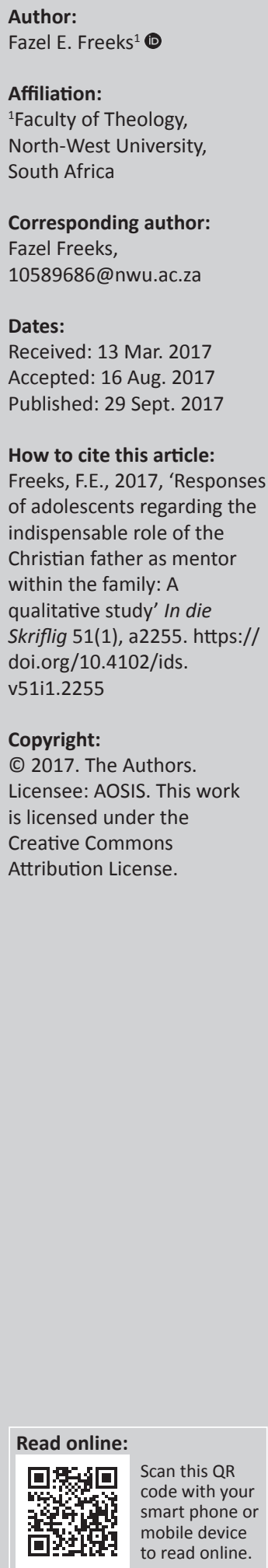

\begin{abstract}
This empirical study explored and described the views about the Christian father as mentor within the family. An explorative, descriptive and interpretive qualitative design was followed in this research using purposive sampling. Respondents were selected by knowledge of the problem of father absence, mentoring, community involvement, leadership and prominence in society. Data was collected by means of in-depth interviews, and field notes were taken after each in-depth interview. Data analysis was conducted using open coding as well as an independent co-coder. The results of the empirical research in which respondents were involved, indicated that the Christian father as mentor is crucial and relevant in the current situation of families. Mentoring by the father is fundamental in the lives of children, and should be implemented and emphasised in the family context. As mentor, the father should nurture their souls and shape their character in order to become complete, whole and, by the grace of God, holy before him.
\end{abstract}

\section{Introduction and problem statement}

In the last several decades, there has been a significant debate sweeping across the world about the present, future and health prospects as well as the complexity of families (Clark \& Clark 2010:37; Freeks 2011:83-84; Welch 2007:2). Dysfunctional family life is a global problem with fatherlessness as the core of the problem (Carstens 2014:10).

Father-absence is a world-wide phenomenon and tendency in all communities (Bartlett 2013:1-3; Dobbs 2013:2; Popenoe 1996; Staples 1999; Williams 2014). Research confirms time and again that fatherhood is essential and that the father still plays a unique role in the development of his children's behaviour, life choices, relationships and self-esteem (cf. Vaughan 2010; Waresak 2016). South Africa was rated in 2012 as one of the countries in the world with the highest figures of father absence (Freeks 2016:6; Richter et al. 2012:2). The South African society has also strayed away in the last few decades from recognising the importance of fatherhood (Ratele, Shefer \& Clowes 2012). Hence, the family is redefined and the father is not even present (cf. Ford et al. 2008). Furthermore, 1.1 million births were registered in 2015 and $64 \%$ indicated that there is no information about the biological father. In 2015, approximately 886202 babies were born and 50\% of the women who gave birth were single mothers with no assistance from the biological father (cf. Frazier 2015; Hawkins 2015; Mkhize 2013:2).

Adolescents are supposed to enjoy a greater advantage when fathers are involved in their lives (Vogel et al. 2006:189-209). Fathers should not only provide money. Adolescents need their fathers in their lives to spend quality time with (Williams 2008:18). The father's value should not be measured by material or financial provision, but by the love and attention he gives to his family. He must also leads by example (Williams 2008:18).

It is important to know that boys are looking at the father as their role model where he leads by example. In the mentoring process, the father should be the role model to his children to enable them to take up their own role of parenthood in the future (Goeke-Morey \& Cummings 2007:221225). Most of the literature used in this article refers to boys, but the article is also applicable to girls (cf. Fagan et al. 2009:1390-1391; Goodsell \& Meldrum 2010:250; Perrin et al. 2009:314; Willerton et al. 2011:521; Wong et al. 2009:454). One of the main reasons why society is in such a bad state is probably the absence of fathers in the lives of children. Therefore, an urgent and immediate appeal should be made to fathers (Williams 2008:18). Children without a father figure 
display uncertainty and confusion. They seek the father's attachment, presence and a lifestyle of living good values. These children want to identify with their fathers and they want a platform of certainty (Ford et al. 2008:284-299).

From the above-mentioned, it is evident that there is a dilemma in terms of the effects of the 'absent' father. Most of the time, the father is present, but neither available, nor supportive or involved in his family. People suffer from broken relationships. A good relationship involves attributes such as motivation, encouragement, nurturing and teaching (Johnson \& Ridley 2004:xv). Needless to say, the father is in many of these instances absent as role model and mentor in the lives of children. This article aims to make a contribution in the field of Practical Theology and specifically towards community engagement as research ${ }^{1}$ and interest.

\section{Research objective}

The research objective of this article is to explore and describe the responses of adolescents in terms of the Christian father as mentor within the family.

\section{Research design}

An exploratory, descriptive, interpretive qualitative and contextual design is used in this article (Thorne 2008, cf. De Vos 2005:267-273; De Vos, Schurink \& Strydom 2001:15; Mouton \& Marais 1992:45). Therefore, the phenomenon that is explored, described and interpreted is the Christian father as mentor within the family. In this article the respondents are also referred to as participants. The term respondents is used, because of the participation of individuals in the bigger study as well as their involvement and interest in the field (cf. Maxwell 1998:94).

\section{Research method}

The method of research that was used for data gathering was in-depth interviews with female adolescents (Botma et al. 2010:204-206). A detailed discussion on how the interviews were conducted is made clear under the section of data gathering.

\section{Permission to conduct research}

Permission to conduct in-depth interviews with adolescents was granted by the research committee of the Faculty of Theology and the Ethics Committee of the North-West University, Potchefstroom Campus as well as the individual respondents in the study (cf. Freeks 2011). Informed consent was given by the individuals (Botma et al. 2010:12, 16-17). This was followed by each respondent signing a consent form that they would partake and that the discussion could be recorded.

1.Compare "The role of the father as mentor in the transmission of values: A PastoralTheological study' (Freeks 2011). The purpose of this article was to determine the essential role of the father as mentor within the family, and therefore the necessity to conduct interviews with fathers, mothers and adolescents - in this case, the to conduct inte

\section{Sample \\ Population}

The population consisted of adolescents. These individuals possessed specific characteristics such as faith in God, respect and love for their fellow man, self-confidence, dedication and all the measurements of interest (cf. Babbie \& Mouton 2001:175; Burns \& Grove 2005:355; Struwig \& Stead 2001:118). They were from the Promosa area in Potchefstroom.

\section{Sampling}

In this study purposive sampling was conducted. In the case of purposive sampling, the choice of the specific respondents was made, because of their knowledge and experience in the phenomenon. They also represented the characteristics or attributes that was needed for the study (cf. Babbie \& Mouton 2001:166-167; Bergh 1998:228-229; De Vos 2005:202). These respondents were selected, because they were involved in the community by having a prominent role in it, and thus showed leadership. These adolescents were matriculants and students, and were carefully chosen according to the criteria listed below (cf. Janse van Rensburg 2009:8; Neuman 2003:210).

The following inclusion criteria were used for the adolescents (Strydom 2005:206):

- They should be part of a family where both parents (mother and father) are present, or if only one parent, they must have another mentor.

- They must be matriculants or older to ensure effective verbalisation.

- They should be confessed Christians and be involved in church activities such as youth programmes, Sunday school, et cetera.

- They must provide informed consent to participate in the study.

- They must be able to express themselves verbally in English or Afrikaans.

- They must consent to the recording of the interviews.

\section{Sample size}

The sample size of the group of female adolescents was determined by data saturation. Data saturation is the point at which no new information is obtained and redundancy is achieved (Pollit \& Beck 2004:308, cf. Botma et al. 2010:202, 290). The group consisted of five female adolescents of whom three were matriculants, and the other two students. Furthermore, three of the adolescents were 18 years old, and the other two were between 17 and 20 years old. Leedy (1997) indicates that qualitative research indeed works on a much smaller scale than quantitative research.

\section{Data gathering}

The respondents were identified in their community and they were contacted by telephone to arrange for an appointment for individual in-depth interviews. Aspects such as anonymity, confidentiality, privacy, risks, withdrawal and even possible termination were discussed (Botma et al. 2010:13-14, 17, 22-24). The physical setting where the 
in-depth interviews were conducted was at the homes of the respondents or at a place of their choice. The settings were private, pleasant and comfortable with little or no distractions (cf. Pinkoane 2005:293).

Only three open-ended questions were formulated to ensure that similar exploration will be done with participants (Botma et al. 2010:134-135). The questions in the interviews were clear, appropriate and understandable. A pilot study was then conducted with an in-depth interview with one adolescent; the data were usable and included in the total data set.

An audio-tape was used to ensure that all information was captured. The voice recorder was placed in such a manner that it did not cause a distraction during the interview. Because the goal in this research was to understand the respondents, rapport was established during the interviews with the respondents by creating a cordial and open atmosphere without any threats or uneasiness (cf. Botma et al. 2010:208; Fontana \& Frey 2000:655). Communication techniques such as paraphrasing, reflecting, summarising, probing, clarifying and minimal verbal responses were used (De Vos 2005:289-290; Okun 1997:70-71). At the end of the interview the respondents were asked if they had anything else to add besides the interview questions that were asked. Most of the respondents added meaningful and relevant information.

The questions for the adolescents were the following:

- Tell me about your experience of having been mentored as a child or young person, either by your father or a father figure?

- Tell me, if you were the father in your house, how would you conduct your role as mentor within the family?

- Anything else you would like to add to our discussion?

Field notes were taken after each interview describing the 'what?', 'where?', 'who?' or 'how?' of the interview. It included written accounts of what the researcher felt, heard, saw, thought and experienced during the interview and were used for verification (Botma et al. 2010:217-219). Field notes were ordered into personal, observational and methodological notes.

\section{Data analysis}

The voice recordings had been transcribed verbatim (Botma et al. 2010:214-215, 227-230; cf. Greeff 2005:298). The method of open coding as described by Cresswell (2009:185-187) were used. The following steps were followed: first, the data for analysis was organised and prepared. Then these data were compared with the field notes to ensure that its meaning was represented correctly. With regard to data analysis an independent co-coder was used (cf. Botma et al. 2010:2-4). The co-coder received copies of the transcriptions, field notes, and a work protocol that indicated the purpose, objectives of the research, method of analysis and the questions as asked to all respondents. The co-coder independently coded the data. A discussion between the co-coder and the researcher then take place where consensus was reached and the data finalised.

\section{Trustworthiness}

Trustworthiness with regard to this article was ensured using the model of Lincoln and Guba (1985 quoted by Krefting 1991:215, 222). This model was summarised by Klopper (2008:70) and tabulated by Botma et al. (2010:232-235).

\section{Ethical considerations}

The respondents were approached and their involvement and participation were explained to them.

The ethical considerations such as right to self-determination, privacy, anonymity or confidentiality and fair treatment were also explained to them (cf. Brink 2007; Burns \& Grove 2005; Strydom \& Delport 2004).

\section{Mentoring}

In the last few years an increase in the focus on mentoring has been experienced as in the field of education, the business sphere, health field, e-mentoring, practical theology, pastoral narratives and also in the family dimension (Fourie \& Van den Berg 2007:94-95; Lotter 2010:6; Masango 2011:3-4; Steytler 2007:12).

What is mentoring in the context of this article? In order to connect and fit such a present-day concept as mentoring in the paradigm of families, it is necessary to describe what it entails. There are many explanations and definitions by various authors concerning mentoring. Hendricks and Hendricks (1995:18) describe a mentor as someone who look inside us and find the person we long to be. Then they help to bring that person to life. At their best, mentors nurture our souls and shape our character. They call us to become complete, whole and, by the grace of God, a holy person.

Tucker (2007:iii, vi) gives an appropriate and applicable explanation and definition of mentoring that supports what is being indicated in this article. He said that mentoring is about relationships and unleashing people's potential and allow them to be the best they can. Further, he indicated that mentoring is a supportive, learning relationship between an individual - the mentor - who shares his or her knowledge, experience and insights with another less experienced person - the learning associate (mentee) - who is willing and ready to benefit from the mentor's knowledge, support and experience. However, De Long, Gabarro and Lees (2008:115-121) claims that mentoring is personal and mentors should provide frequent and fair authentic advice and nurturing. Mentors are sometimes the offline help by one person to another in making significant transitions in knowledge, work or thinking (cf. Allen \& Eby 2007:9-12; Clutterbuck \& Megginson 1999:3; Corey \& Corey 2007; Derrick \& Dicks 2005:9-10; Herman \& Mandel 2004:1-2; Johnson \& Ridley 2004:xv; Megginson et al. 
2006:4-5; Mulaudzi, Libster \& Phiri 2009:49; Rudney \& Guillaume 2003:2).

Steytler (2007:39), on the other hand, explains a mentor as an older person who does not only believe in the younger person, but who also leads and empowers the younger person. This specific mentor has an open relationship with the younger person so that trust may develop between them. Sometimes these mentoring relationships are quite complex, but the core is the everyday interactions through which growth and development occur (Wood \& Duck 2006:156). Mentoring should not be limited to a specific age as Steytler indicated above, but should be applied to all ages and stages of the mentee irrespective the mentor's skills or experience in the field of mentoring. Mentoring is all about the pairing of a more experienced individual with a less experienced one and in this relationship, mentees with less experience or less skill are able to develop their capabilities through the guidance and support of more seasoned people like the Christian father (Masango 2011:3-4; Wood \& Duck 2006:156).

Hence, proper mentoring with a longer duration may even go beyond these definitions and lead to a mature friendship and reciprocal mentoring as I have experienced in my field of study. Nevertheless, in order to have a clear understanding of the concept mentor in correlation with the Christian father within a family, it is fundamental to have a look at the origin of a mentor and the attributes of a mentor.

Hendricks and Hendricks (1995:17-18), Fourie and Van den Berg (2007:94-95), and Steytler (2007:12) reflect on the concept by indicating the following: Odysseus was a Greek combatant who fought in the Trojan War. He left his son in the hands of someone he trusted (confidant) with the name of Mentor. The war lasted for 10 years and it took Odysseus another 10 years to return to his home. When Odysseus finally returned to his home, he experienced and witnessed that his son, Telemachus, was fully mature (had become a person of good values) due to the influence of Mentor. In the context of this article and according to the perspective of this narrative, a mentor is someone who has an immediate or direct influence on someone's life and that could possibly be the reason why mentoring has been developed through the ages.

A successful mentor should encourage, motivate, nurture, teach and practice mutual respect (Johnson \& Ridley 2004:xv; cf. also Lotter 2007; Pelletier 2006:46;). What constitutes a mentor is crucial in this article. A good mentor is a person who is absolutely credible and has a high level of integrity. He or she listens and responds in ways that show that the hearer has been understood. He encourages and gives the mentee confidence that he or she can move forward despite inner doubts and fears. The mentor gives honest feedback without being demeaning. He interacts in ways that are respectful and that encourage the mentee to do better and to take risks. He also shares ideas, presents opportunities and challenges that the person being mentored may not have seen or recognised as possibilities. He is not threatened by the mentee's capabilities and opportunities to succeed and get ahead. Instead, good mentors encourage others and are not too proud to learn from the mentee's questions and experiences (Collins 2008; cf. also Pelletier 2006:6).

From this essential discussion regarding mentoring, it is clear that the above-mentioned aspects of mentoring may be applied to the Christian father as mentor within the family. For example, fathers may help their children to learn the basics of walking with Christ (disciple). They can teach their children how to develop into mature Christianity (spiritual guide). Fathers may also help them to learn to do things by themselves such as application and admission to universities and independent studies (coach). Furthermore, fathers may help them by giving good advice that will help them through difficult situations and challenges in life (counsellor), and the father should also help them to learn the essential ideas and get perspectives in life. That will lead to good and quality decision making later in their lives. In fact, the father ${ }^{2}$ (mentor) should be a guide who helps the adolescent (mentee) to find the right direction in life (teacher).

\section{Results of the study}

Results obtained from respondents are discussed. Richness is provided by verbatim quotes and a literature control to validate findings. The purpose of literature control is to compare the findings of the study with existing literature and to draw conclusions (cf. Botma et al. 2010:196-197).

\section{Results from in-depth interviews with adolescents}

The following two themes emerged for the adolescents during the analysis of data. These themes indicated respondents' opinions, views, perceptions and ideas with regard to the essential role of the Christian father within the family. The first theme reflects on the experience of fathering. The second theme indicates the aspect of if I were the father in the house. These themes are discussed in detail including the sub-categories.

\section{Theme one: adolescents' experiences of fathering}

The first theme portrays the adolescents' experiences of mentorship. Adolescents indicated that they were mentor by father figures. Specific sub-category findings are the following:

Believe in yourself and in your dreams and goals: Adolescents indicated that they experienced being mentored by their biological fathers, mothers, pastors, teachers and grandfathers. Respondents expressed their feelings in words: 'you should believe in yourself'; 'believe in the things that you want to achieve'; 'study hard'; 'you can achieve your goals'; 'your dreams will be realized'.

The findings are supported by Freeks (2008:1-6). He states that people should believe in themselves, because most

2.Due to father absence and fatherlessness in many cases, participants reported during interviews that they had mentors and father-figures in their lives to fill the gap of the biological father (Freeks 2011). 
people in life have a distorted picture of themselves, and they also have a distorted picture of how God sees and looks at them. They should also grasp and understand the fact that God made them perfectly and wonderfully (cf. Ps. 139:14). Williams (2008:18) also supported the findings and indicates that fathers should love their children unconditionally. Fathers should praise their children whenever they accomplish a noteworthy feat.

Also believe in God: Respondents reported that their fathers requested them not only to believe in them as fathers and other father figures, but also to believe in God as their heavenly Father. Respondents expressed their fathers' views in words: 'believe also in God'; 'God is there and you can get help from Him'.

These findings are supported by Gushee (1995:442). He indicates that children should not only believe in God, they should also love God with all their heart, soul and with all their strength (cf. Dt 6:5-8). If children believe in God, their faith will develop in God and also their relationship through the Holy Spirit. God is the One who helps when children experience all sorts of problems such as contemplating suicide, drugs, alcohol, et cetera.

The father is a rock in the house and in the lives of children: Respondents mentioned that their fathers are the rocks in their lives, because they did a great job raising them. They expressed their views in words: 'the father is the rock in the house'; 'children should trust and depend on their fathers'; 'he showed us the right direction'.

These findings are supported by Steytler (2007:54-55 \& 61). He indicates that the father's role is steady, because he serves as an example, role model, educator and listener as he provides knowledge, advice, counselling, support and opportunities. The father himself has the need to listen to his children when they approach him with whatsoever.

The fathers is an anchor in the family: Respondents indicated that their fathers are anchors in their lives. They expressed their views in words: 'fathers are anchors in the family'; 'parents are protective over their families'; 'fathers are trying very hard to keep us on the right track'; 'they warned us to not repeat the same mistakes and not to use drugs'.

Groenendyk and Volling (2007:205) support the findings in their research. They indicated that good parenting results in warmth and prevents behavioural problems within children. Bergh (2002:19) also supports the findings by pointing out the fact that the father is the priest of the house or family. He is the one who presents his family before God (cf. Freeks 2008:24-25). Cohen (2001:5) indicates that the impact of the father in the lives of his children results in happier families.

\section{Theme two: If I were the father in the house}

These sub-category findings include the following aspects:
What a father should do?: Respondents indicated that they would do their best to keep their children on the right way and away from bad things. They expressed their views in words: 'I would try my utmost best to keep my children on the right track or path'; 'as a father I would discipline them'; 'I would try to avoid that my children do the wrong and bad things'; 'I would teach my children the difference between right and wrong'; 'I will set the example'.

The findings are supported by Freeks (2007:48) in his study. He underlines the aspect of self-discipline as a huge problem in South Africa. He further mentions that this dilemma creates frustrations and it can be a stumbling block for the father (cf. also Euvrard 2006:3-4). The father's role is to be an example to his children, to point out their mistakes and give them guidance that they should not repeat the same mistake (Freeks 2004:93).

Children should be taught not to do bad things: Respondents indicated that they would make their children aware of the bad things such as drinking, smoking, swearing, et cetera. They expressed their views in words: 'don't do bad things such as drinking; smoking and swearing'; 'there are consequences if you are doing the things you not supposed to do'.

Engelbrecht (2001:32-34, cf. also Lepholletse 2008:1-3) indicates in his research that children are exposed to bad dilemmas such as violence, gang-rape, drinking or alcohol abuse, rave parties, drugs, free sex, et cetera. Parents are concerned and try everything in their power to stop this slide in values and bad behaviour (cf. Freeks 2007:1).

Children should be taught to stay away from bad friends and wrong places: Respondents indicated that they would encourage their children to stay away from bad friends and wrong places. They expressed their views in words: 'you should get away from bad friends and their influences'; 'don't go to wrong places'; 'choose good friends'.

According to Larney and Lotter (2005:663-664), the key role of parents is the transmission of ethical and moral values with regard to children. When parents apply this golden rule, it is evident that children will benefit when they develop as adults. Thus, parents should encourage their children to distinguish between right and wrong, and make a priority of avoiding wrong places and friends.

A father should be strict at home: Respondents implied that if they were the father in the house they should be sometimes very strict but with love. They expressed their views in words: 'I will be strict but with love'; 'I will not put my children in prison or keep them in bondage but will be strict to them'; 'I will give them some freedom but if I need to punish them, I will punish them'.

The findings are supported by Freeks (2004:93) in his research. He indicates that the father should be strict in his education with regard to his children. He should not only punish them, 
but also gives them lots of love. In her research, De Klerk (2004:3) points out the aspect of discipline and self-discipline as rules of the strict father that children should obey. She says that self-discipline is the end result of moral development.

Children should learn to trust their parents: Respondents said that they would teach their children to trust them as parents, because trust is a very important value. They expressed their views in words: 'children should trust you as parent and disclose certain things that bother them'.

Bergh (2002:119) confirms the findings in his research. He indicates that a strong bond between parents and children are essential. This bond creates a trust between parent and child so that children will take the liberty to consult their parents when they are exposed to problem situations.

Fathers should spend more time with their daughters: Respondents mentioned that fathers should spend some time with their daughters. They expressed their views in words: 'fathers should sit down and talk to their children because young people are facing a lot of things outside and they don't know how to handle it'; 'fathers must explain to their daughters why they can't date'; 'they must not shout and chase our boyfriends out of the house'; 'fathers must spend more time with their daughters by taking them out and show how a girl must be treated by another guy'.

O'Connor et al. (2006:504) state in their research that conflict between fathers and sons are more common than conflict between fathers and daughters. This implies that fathers should not spend more time with daughters, but spend equal time with his children. He should advise and make his daughters more alert and cautious to the dangers outside. Freeks (2004:93-95) indicates in his research that children (sons and daughters) sometimes experience the feeling that one child is more privileged and fortunate than another. $\mathrm{He}$ says that the father should act fair, righteous and with love in that particular situation. Towards the daughter the father should be protective and towards his son his role should be one of identification, because the son has to follow the example of the father to carry out certain responsibilities. Steytler (2007:77) mentions in his study that the presence and involvement of the father are of the essence to his children. Therefore, quality time-spending with children (sons and daughters) is paramount. Children have a need for their parents' time and not their money or gifts. It should be a good habit of the father to take his children out for meals, educational activities, films, theatres, et cetera to strengthen the bond between them (cf. Freeks 2004:92).

\section{Findings}

The findings suggest that the father should be consistent in his role as mentor. He should not be partially involved in the lives of his children, but rather be present and available, especially when they face challenges outside the home. Further, the aspect of discipline is mentioned as important, and therefore respectful communication seems as a very important dimension in the responses of participants. Fathers must maintain discipline in their homes, because of the dilemma that families are experiencing with undisciplined adolescents. Another important finding in the responses of adolescents is the aspect of God where participants are advised by their fathers and other father figures to believe in God, and trust that God can help them in their daily lives.

\section{Conclusion}

When participants were asked about their overall view of the father as mentor, the general response was their desire and expectation that the father should be present and available within the home. Furthermore, they agreed on the importance of mentoring as part of the role of the father within the family.

\section{Acknowledgements}

\section{Competing interests}

The author declares that he has no financial or personal relationships which may have inappropriately influenced him in writing this article.

\section{References}

Allen, T.D. \& Eby, L.T., 2007, The Blackwell handbook of mentoring: A multiple perspectives approach, Blackwell Publishing, Malden, USA.

Babbie, E. \& Mouton, J., 2001, The practice of social research, Oxford University Press, Cape Town.

Bartlett, E., 2013, 'Die impak van afwesige vaders op adolessente meisies se psigososiale welstand', Hons-skripsie, Noordwes-Universiteit, Potchefstroomkampus.

Bergh, B.L., 1998, Qualitative research methods for the social sciences, 3rd edn, Allyn \& Bacon, Boston, MA.

Bergh, S.J., 2002, 'Gesinsbediening as 'n geïntegreerde deel van die opbou van die gemeente', DTh-proefskrif, Universiteit van die Oranje Vrystaat, Bloemfontein.

Botma, Y., Greeff, M., Mulaudzi, F.M. \& Wright, S.C.D., 2010, Research in health sciences, Clyson Printers, Cape Town.

Brink, H., 2007, Fundamentals of research methodology for health/care professionals, 2nd edn., Juta, Cape Town.

Burns, N. \& Grove, S., 2005, The practice of nursing research, conduct, critique and utilization, 5th edn., Elsevier Saunders, St. Louis, MO.

Carstens, C., 2014, The world needs a father: A trainers' guide, Paarl Media Printers, Cape Town.

Clark, D. \& Clark, C., 2010, 'Connecting and serving today's adolescent: Six new realities that impact our work with kids', Christian Counselling Today 18(2), 37-39.

Clutterbuck, D. \& Megginson, D., 1999, Mentoring executives and directives, Butterworth-Heinemann, Johannesburg.

Cohen, D., 2001, The father's book: Being a good dad in the 21st century, Wiley, Chichester.

Collins, G.R., 2008, What makes a mentor: Post traumatic growth, Newsletter 278, email, 07 February, grc@garyrcollins.com.

Corey, M.S \& Corey, G., 2007, Becoming a helper, Thomson, Brooks/Cole, Belmont.

Cresswell, J.W., 2009, Research design: Qualitative, quantitative, and mixed methods approaches, 3rd edn., Los Angeles, Sage Publication.

De Klerk, J., 2004, 'Waardes in die onderwys' Die Unie, Junie, pp. 1-4.

De Long, T.J., Gabarro, J.J. \& Lees, R.J., 2008, 'Why mentoring matters in a hypercompetitive world', Harvard Business Review 86(1), 115-121.

Derrick, J. \& Dicks, J., 2005, Teaching practice and mentoring: The key to effective literacy, language and numeracy teacher training, National Institute of Adult Continuing Education, Leicester, Wales.

De Vos, A.S., 2005, 'Qualitative data analysis and interpretation', in A.S. De Vos, H. Strydom, C.B. Fouché \& C.S.L. Delport (eds.), Research at grass roots, for the social sciences and human service professions, 3rd edn., pp. 333-334, Van Schaik, Pretoria.

De Vos, A.S., Schurink, E.M. \& Strydom, H., 2001, 'The nature of research in the caring professions', in A.S. De Vos (ed.), Research at grass roots. A primer for the caring professions, pp. 3-22, Van Schaik, Pretoria.

Dobbs, P., 2013, 'The impact of fatherlessness on the way one relates to God as Father', MA-dissertation, University of Otago. 
Engelbrecht, T., 2001, 'Van ashoop na hoop: Is waarde-onderrig die antwoord op SuidAfrika se morele verval?', De Kat 16(7), 32-34.

Euvrard, G., 2006, 'The values manifesto project', Educational Leadership 63(8), 1-6.

Fagan, J., Palkovitz, R., Roy, K. \& Farrie, D., 2009, 'Pathways to paternal engagement: longitudinal effects of risk and resilience on non-resident fathers', Development Psychology 45(5), 1389-1405.

Fontana, A. \& Frey, J.H., 2000, 'The interview: From structured questions to negotiated text', in N.K. Denzin \& Y.S. Lincoln (eds.), Handbook of qualitative research, pp. 645-672, Sage, Thousand Oakes, CA.

Ford, J.J., Nalbone, D.P., Wetchler, J.L. \& Sutton, P.M., 2008, 'Fatherhood: How differentiation and identity status affect attachment to children", American of Family Therapy 36(4), 284-299. https://doi.org/10.1080/01926180701647074

Fourie, M. \& Van den Berg, J.A., 2007, 'The development of pastoral narrative mentorship principles as effective learning approach', Acta Theologica 27(2), 92-104.

Frazier, T., 2015, 'The result of fatherlessness in South Africa', viewed 20 June 2017 from http://www.tumifrazier.com/fatherlessness-in-south-africa/

Freeks, F.E., 2004, 'Die rol van die ontbrekende vaderfiguur in die Suid-Afrikaanse konteks. 'n Prakties-teologiese studie', MA-verhandeling, PU vir CHO, Potchefstroom.

Freeks, F.E., 2007, "n Karakterbouprogram vir verdere onderwys en opleidingskolleges', PhD-proefskrif, Noordwes-Universiteit, Potchefstroom.

Freeks, F.E., 2008, Manual for course facilitators: Lifeplan ${ }^{\oplus}$. Africa Unit for Transdisciplinary Health Research (AUTHeR), North-West University, Potchefstroom, South Africa.

Freeks, F.E., 2011, 'The role of the father as mentor in the transmission of values: A pastoral-theological study', PhD thesis, North-West University, Potchefstroom Campus.

Freeks, F.E., 2016, 'Die noodsaak van Skrifgefundeerde vaderskap as antwoord op die voortslepende probleem van vaderafwesigheid in Suid-Afrika', Tydskrif vir Christelike wetenskap 52(1\&2), 1-27.

Goeke-morey, M.C. \& Cummings, E.M., 2007, 'Impact of father involvement: A closer look at indirect effects models involving marriage and child adjustment', Applied DevelopmentScience11(4),221-225.https://doi.org/10.1080/10888690701762126

Goodsell, T.L. \& Meldrum, J.T., 2010, 'Nurturing fathers: a qualitative examination of child-father attachment', Early Child Development and Care 180(1\&2), 249-262.

Greeff, M., 2005, 'Information collection: interviewing', in A.S. de Vos, H. Strydom, C.B. Fouché \& C.S.L. Delport (eds.), Research at grass roots for the social sciences C.B. Fouché \& C.S.L. Delport (eds.), Research at grass roots for the
and human service professions, pp. 286-313, Van Schaik, Pretoria.

Groenendyk, A.E. \& Volling, B.L., 2007, 'Co-parenting and early conscience development in the family', The Journal of Genetic Psychology 168(2), 201-224. https://doi.org/10.3200/GNTP.168.2.201-224

Gushee, D.P., 1995, 'Christian fatherhood: A moral paradigm for the age of fatherlessness', Review and Expositor 92, 435-448.

Hawkins, C., 2015, 'Most SA households run by single moms', SA Breaking News, 3 September, viewed 20 June 2017, from http://www.sabreakingnews.co. za/2015/09/03/most-sa-households-run-by-single-moms/

Hendricks, H. \& Hendricks, W., 1995, As iron sharpens iron: Building character in a mentoring relationship, Moody Press, Chicago, IL.

Herman, L. \& Mandell, A., 2004, From teaching to mentoring: Principle and practice, dialogue and life in adult education, RoutledgeFalmer, London.

Janse van Rensburg, J., 2009, 'Seminar on research methodology', paper presented at Faculty of Theology, North-West University, Potchefstroom, 30-31 August.

Johnson, W.B. \& Ridley, C.R., 2004, The elements of mentoring, Palgrave Macmillan New York.

Klopper, H., 2008, 'The qualitative research proposal' Curationis 31(4), 62-72. https:// doi.org/10.4102/curationis.v31i4.1062

Krefting, L., 1991, 'Rigor in qualitative research: The assessment of trustworthiness', American Journal of Occupational Therapy 45(3), 214-221. https://doi.org/ 10.5014/ajot.45.3.214

Larney, T. \& Lotter, G.A., 2005, 'Ouers se rol in die oordrag van etiese en morele waardes', Koers 70(4), 661-683. https://doi.org/10.4102/koers.v70i4.287

Leedy, P.D., 1997, Practical research: Planning and design, 6th edn., Prentice Hall, Upper Saddle River, NJ.

Lepholletse, A.M.M., 2008, 'Teacher's influence on the value-orientation of learners in secondary schools', PhD-thesis, North-West University, Potchefstroom.

Lincoln, Y.S. \& Guba, G.E., 1985, Naturalistic inquiry, Sage, London.

Lotter, G.A., 2007, Pastorale Teologie: Voëlvlug en (voorlopige) landing, NWU, Potchefstroom

Lotter, G.A., 2010, 'E-mentoring as effective tutoring tool in higher education', paper presented at the Mentoring Conference, Durban, 2-5 September.

Masango, M., 2011, 'Mentorship: A process of nurturing others', HTS Theological Studies 67(1), 5 pages. https://doi.org/10.4102/hts.v67i1.937

Megginson, D., Clutterbuck, D., Garvey, B., Stokes, P. \& Garret-Harris, R., 2006, Mentoring in action: A practical guide, Kgan Page, London.

Maxwell, J.A., 1998, 'Designing a qualitative study', in L. Bickman \& D.J. Rog (eds.), Handbook of applied social research methods, pp. 69-100, Sage, Thousand Oakes, CA.
Mkhize, V., 2013, 'Black, young poor and fatherless', Star, 19 November, p. 2

Mouton, J. \& Marais, D.C., 1992, Basic concepts in the methodology of social sciences, R.G.N. Publishers, Pretoria.

Mulaudzi, F.M., Libster, M.M. \& Phiri, S., 2009, 'Suggestions for creating a welcoming nursing community: Ubuntu, cultural diplomacy, and mentoring', International Journal for Human Caring 13(2), 45-51.

Neuman, W.L., 2003, Social research methods: Qualitative and quantitative approaches, 5th edn., Allyn \& Bacon, Boston, MA.

O'Connor, T.G., Dunn, J., Jenkins, J.M. \& Rasbash, J., 2006, 'Predictors of betweenfamily and within-family variation in parent-child relationships', Journal of Child
Psychology and Psychiatry 47(5), 498-510. https://doi.org/10.1111/j.1469Psychology and Psyc
7610.2005.01527.x

Okun, B.F., 1997, Effective helping: Interviewing and counselling techniques, Brooks/ Cole, Pacific Grove, CA.

Pelletier, C., 2006, Mentoring in action: A month-by-month curriculum for mentors and their new teachers, Pearson Education, Inc., Boston, MA.

Perrin, P.B., Baker, J.O., Romelus, A.M., Jones, K.D. \& Heesacker, M., 2009, 'Development, validation, and confirmatory factor analysis of the father hunger scale', Psychology of Men \& Masculinity 10(4), 314-327.

Pinkoane, M.G., 2005, 'Incorporation of traditional healers into the national health care delivery system', PhD thesis, North-West University, Potchefstroom.

Pollit, D. \& Beck, C., 2004, Nursing research, principles and methods, 7th edn., Lippincott Williams \& Wilkins, Philadelphia, PA

Popenoe, D., 1996, 'A world without fathers', Wilson Quarterly 20(2), 12-16.

Ratele, K., Shefer, T. \& Clowes, L., 2012, 'Talking South African fathers: A critical examination of men's constructions and experiences of fatherhood and fatherlessness', South African Journal of Psychology 42(4), 553-563. https://doi. org/10.1177/008124631204200409

Richter, L., Desmond, C., Hosegood, V., Madhavan, S., Makiwane, M., Makusha, T. et al. 2012, 'Fathers and other men in the lives of children and families', paper presented at the 'Towards Carnegie III' Conference at the University of Cape Town, 3-7 September, viewed 20 June 2017, from https://www.google.com/url?sa=t\&rct=j\&q= \&esrc=s\&source=web\&cd=1\&ved=0ahUKEwjlisjF3ITOAhVBD8AKHaOuB9gOFggfMA \&esrc $=s \&$ source $=$ web \&cd $=1 \&$ ved $=0$ ah $U$ KEW jlisj $F 31$ QAhVBD8AKHaQuBggQFggfM A\&url=http $\% 3 \mathrm{~A} \% 2 \mathrm{~F} \% 2 \mathrm{Fcarnegie3.org} . \mathrm{za} \% 2 \mathrm{Fdocs} \% 2 \mathrm{Fpapers} \% 2 \mathrm{~F} 231$ Richter_Fat hers $\% 2520$ and $\% 2520$ other $\% 2520$ men $\% 2520$ in $\% 2520$ the $\% 2520$ lives $\% 2520$ of $\% 2$ 520children $\% 2520$ and $\% 2520$ families.pdf\&usg=AFQjC
KIKx18b4RFKw\&sig2=VO4Zh-Crp6uCCOD1WuuJjg\&cad=rja

Rudney, G.L. \& Guillaume, A.M., 2003, Maximum mentoring: An action guide for teacher trainers and cooperating teachers, Corwin Press Inc., Thousand Oaks, CA.

Staples, R., 1999, The black family, Wadsworth Publishing, Belmont, CA.

Steytler, J.P.D., 2007, 'Mentorskap in die maatskaplike funksionering van die seun in sy laat-middelkinderjare', MA-verhandeling, Noordwes-Universiteit, Potchefstroom.

Struwig, F.W. \& Stead, G.B., 2001, Planning, designing and reporting research, Masker Miller Longman, Cape Town.

Strydom, H., 2005, 'The pilot study', in A.S. De Vos, H. Strydom, C.B. Fouché \& C.S.L. Delport (eds.), Research at grass roots. For the social sciences and human service professions, 3rd edn., p. 206, Van Schaik, Pretoria.

Strydom, H. \& Delport, C.L.M., 2004, 'Research at grass roots - For social sciences and human service professions', in A.S. De Vos (eds.), Research at grass roots for the social sciences and human service professions, p. 493, Van Schaik, Pretoria.

Thorne, S., 2008, Interpretive description, Left Coast Press, Walnut Creek, CA.

Tucker, K., 2007, Establishing a mentoring and coaching programme, Knowres Publishing, Randburg.

Vaughan, J., 2010, 'Dads and the daughters they love', viewed 20 June 2017, from http://www.focusonthefamily.ca/parenting/fatherhood/dads-and-the-daughtersthey-love

Vogel, C.A., Bradley, R.H., Raikes, H.H., Boller, K. \& Shears, J.K., 2006, 'Relation between father connectedness and child outcomes', Parenting 6(2/3), 189-209. https://doi.org/10.1207/s15327922par0602\&3_4

Waresak, J.T., 2016, '5 keys to lead your wife' i.e. 'Wear the pants', viewed 20 June 2017, from http://www.drjamesdobson.org/blogs/the-fatherhood-challenge/the2017, from http://www.drjamesdobson.org/blogs/the-fatherhood-challenge/the-
fatherhood-challenge/2016/06/22/5-keys-to-lead-your-wife-ie-wear-the-pants

Welch, K.J., 2007, Family life now: A conversation about marriages, families, and relationships, Pearson Education, Inc., Boston, MA.

Willerton, E., Schwarz, R.L., Macdermid, J., Wadsworth, S.M, \& Oglesby, M.S., 2011, 'Military fathers' perspectives on involvement', Journal of Family Psychology 25(4), 521-530.

Williams, A., 2008, 'We badly need good fathers', Human Events 64(21), 18.

Williams, R.B., 2014, 'The male identity crisis and the decline of fatherhood', Psychology Today, viewed 20 June 2017, from http://www.psychologytoday.com/ em/152400

Wong, M.S., Mcelwain, N.L. \& Halberstadt, A.G., 2009, 'Parent, family, and child characteristics: associations with mother- and father- reported emotion socialisation practices', Journal of Family Psychology 23(4), 452-463.

Wood, J.T. \& Duck, S., 2006, Composing relationships: Communication in everyday life, Thomson Wadsworth, Belmont, Canada. 